\title{
The Characteristics of the Map Merging Methods: A Survey
}

\author{
Ilze Andersone, Riga Technical University
}

\begin{abstract}
The development of the autonomous mobile robots is a popular field of research in the artificial intelligence for more than twenty years. An important prerequisite for creation of autonomous robot is the ability to create a map of the environment. However there are several problems in the robotic mapping that are still not completely solved. The use of multiple robots for mapping solves some of these problems, but in this case several new problems, specific to multi-robot mapping, arise. One of the problems in multi-robot mapping is merging all of the local maps that robots have created into one global map. The application of the robot teams in the exploration is a relatively new research field and initially methods for multi-robot mapping were just extended single robot mapping methods. Consequently the map merging problem was simplified. The research of map merging has only recently evolved, thus existing papers on the map merging describe specific map merging methods and there are no comprehensive surveys on the state of the art in the field of map merging. Therefore the goal of this paper is to describe the situation in the field of the map merging and to identify the main characteristics of the map merging methods. The interrelations of these characteristics can then be identified and the corresponding map merging approaches of each characteristic set named.
\end{abstract}

Keywords: map merging, robot teams, robotic exploration, robotic mapping

\section{INTRODUCTION}

The development of the autonomous mobile robots is a popular field of research in the artificial intelligence since 1980s [1]. Research is motivated by the many possible applications of autonomous mobile robots, which include planetary exploration, reconnaissance, rescue, mowing, and cleaning [2]. One of the fundamental problems in mobile robotics that has to be solved is the environment mapping problem. Robots need to be able to construct a map of the environment and to use it for the navigation.

A lot of research has been dedicated to the single robot mapping. However, there are problems that are hard to solve, such as measurement errors, high dimensionality of mapping, or data correspondence [1]. The use of multiple robots for mapping can solve some of these problems [3], and it also offers several other advantages over single robot mapping. Often it is possible to create a map of the environment faster with multiple robots than with only one robot $[2,4]$. Multirobot mapping teams are more fault tolerant than single robot platforms, as the defection of one robot does not necessarily imply the termination of mapping process. Multiple robots can also use different sensors for mapping, thus improving the quality of resulting map [5].

Robot teams originated in late 1980s [6], however only during the last ten years has the multi-robot mapping question been intensively studied. This may be due to the fact that, although robot teams offer multiple advantages over single robot platforms, several new problems, specific to the multirobot mapping, arise [3].

From all the multi-robot mapping problems only map merging is considered in this paper. When a robot explores, it collects the information about the environment by using sensors. If multiple robots are used for the exploration of the environment, their collected information has to be fused into one general global map. The fusion of the map information from multiple robots into one global map is called map merging [7].

As Konolige et al. notes, "map merging is an interesting and difficult problem, which has not enjoyed the same attention that localization and map building have" [8]. Although several years since this statement have passed and the map merging problem has received more attention, most of the published papers on the matter are descriptions of specific map merging methods. There are no comprehensive surveys where the information about existing map merging methods would be collected. Consequently no real classification of map merging methods exists. Therefore the goal of this paper is to summarize the information about the existing work in the field of map merging and to identify main characteristics of the map merging methods. The identified characteristics are then further used for the classification of the map merging approaches.

The structure of this paper is as follows. At first the related work is discussed in Section II. Then the existing map merging approaches are divided into three groups and described in Section III. From the described map merging approaches the most important map merging characteristics and their possible values are identified and described in Section IV. Section V shows the identified relationships between the values of the characteristics and how to use these relationships for the classification of map merging approaches. Finally, the conclusions are drawn and possible future work defined.

\section{RELATED WORK}

The map merging is still a new research field, so there are no comprehensive surveys available on the matter. However, there are some trends in existing publications that are used in this paper for the identification of characteristics of map merging methods.

The robot mapping has been researched intensively for a long time and a lot of progress has been made. Naturally there have been attempts to summarize and to classify the existing 
methods. One of such work is Thrun's survey on robotic mapping [1]. This comprehensive survey classifies robot mapping methods and offers insight in each of the classes. However, this survey focuses almost exclusively on single robot mapping and only brief information is available about mapping with robot teams. On the matter of distributed mobile robotics a summarizing paper has been written by Parker [6]. Yet only a small part of this work is devoted to the multi-robot localization, mapping and exploration problem. Besides the section on this problem only discusses the usefulness of multirobot mapping compared to single robot mapping and doesn't try to immerse into multi-robot mapping problems.

However, there are papers where mapping problems with multiple robots are considered. Initially the most research activity was dedicated to multi-robot mapping issues other than map merging. For this reason the situation in multi-robot mapping subfields, such as localization [9], [10], coordination and exploration [2], [4], [11], and rendezvous arrangement [12], is better defined than in map merging.

The subfield of the map merging is less familiar than other multi-robot mapping subfields mentioned above. Nevertheless there are several authors who have become acquainted and shortly described the situation in the map merging research area [7], [13] - [16]. However, these reviews are incomplete and often outdated. In most cases the map merging is considered in the context of the specific case study and only closely related works are reviewed. Still, several patterns are common in the existing classifications of map merging methods. Often map merging methods are grouped by the robots' knowledge of the relative positions or the reference frames [7], [13] - [16]. Other characteristic that is often used for the classification of map merging methods is the type of the maps used in the merging [13], [16]. An exception is made by Konolige et al. [8], who groups the methods by their ability to make a decision when maps can be safely merged and when the merging is not possible.

There are several reviews of map merging methods. However, they all share a common trait - the situation in the area is considered in the context of the particular research. It is meant to show the reader why their work is important and not to comprehensively describe the existing state of the art in map merging. A couple of map merging characteristics have been identified (knowledge about the robot positions, type of the maps, decision making) but there are more properties that are important in the context of map merging. This paper describes the familiar characteristics of map merging as well as introduces less popular characteristics like structure of the environment, enabler of the map merging, and time required for the map merging. All these characteristics are important if one needs to choose the implementation of map merging.

\section{The OVERVIEW OF THE MAP MERGING Methods}

One of the fundamental problems in multi-robot mapping is merging all of the local maps that robots have created into one global map. However, it is not a trivial matter and some kind of map merging algorithm is required.

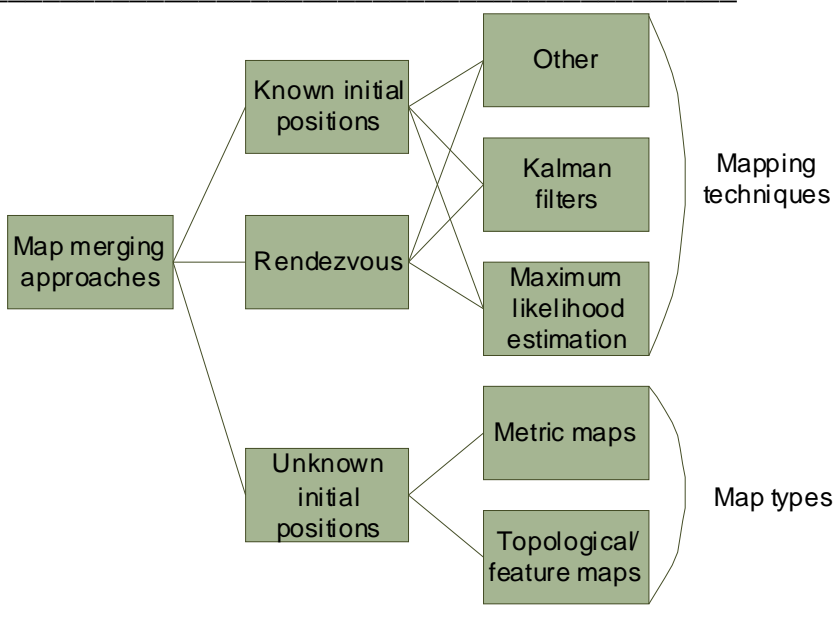

Fig. 1. The variety of map merging approaches

An interesting pattern was discovered by analyzing different map merging methods. If the relative reference frames of the robots are known initially or acquired during the rendezvous, the main attention of the researchers is focused on the mapping techniques. On the contrary, if the relative positions of the robots are never determined, the main emphasis is put on the feature extraction from raw sensor data or the map type. Therefore the map merging approaches can be roughly divided in several groups as depicted in Fig. 1.

\section{A. Map Merging when the Initial Relative Positions of the Robots Are Known}

Initially multi-robot mapping methods were simply extended single robot mapping methods [6]. Consequently the map merging problem was also simplified by assuming that the robots create their maps in common reference frame. For this approach to work usually the robots must know their relative starting positions. Several authors have developed multi-robot mapping methods based on this assumption.

One of the first researches in multi-robot mapping dates back to the 1993, when Ishioka et al. [5] implemented and described an algorithm that was able to merge the local maps of two robots once the overlap of the maps was identified. The merging of the local maps was accomplished by rotating and sliding the maps until the best match was found. The task was alleviated by the fact that the initial starting positions and wheel slippage ratios of the robots were assumed to be known. These assumptions significantly reduce the search space of the transformations.

Thrun et al. [17], [18] combines the idea of posterior estimation with incremental map construction using maximum likelihood estimation to create the mapping algorithm that enables data integration from multiple robots. Though the starting locations of the robots aren't assumed to be known, there is a restricting assumption that each robot starts in the map of one specific robot, the team leader. Robots localize themselves in this map and only then the mapping process begins. In reality this means that the relative positions are known when the mapping starts.

The mapping algorithm devised by Simmons et al. [4] also uses the maximum likelihood estimation. The relative 
positions of the robots are assumed to be approximately known and their algorithm is able to deal with small starting position errors.

One more application of the maximum likelihood estimation is found in the work by Howard et al. [19]. The main difference from the other works is the use of the manifold maps. The manifold maps represent the environment in a higher-dimensional space as multiple overlapping layers. Besides the different environment representation the authors use the robot meetings to make a data correspondence problem easier.

Mapping methods described above use the maximum likelihood estimation for mapping. Another possible option is to use the Kalman Filter. There are several researchers that have based their mapping algorithm on this technique [9], [20], [21]. Although the main idea is similar, some differences exist between these approaches. Fenwick et al. in [20] assume that distinctive environment features can be extracted from raw sensor data. These features are then used to localize the robot and improve feature estimates, which are updated using an Extended Kalman Filter. Madhavan et al. [9] turn their main attention to the distributed localization problem. The approach by Rodriguez-Losada et al. described in [21] deals with robots who independently construct their local maps and only fuses the local map with global map from time to time. Both the local map and the global map constructions are implemented with the Kalman Filter. The restriction on the known relative positions of the robots, however, is still there.

Another approach to the mapping is attempted by Ceccarelli et al. [22]. They use a set membership localization and map building to construct the map of the environment. Like most approaches described above, the local maps of the robots are merged at the beginning of the mapping with the knowledge of relative starting positions. Each robot then updates the global map as the mapping proceeds.

\section{B. Map Merging when Robots Identify Their Relative Positions During the Mapping}

An alternative to giving the robots their relative positions at the start of the mapping is to use a rendezvous strategy. In this case, the robots create their maps independently until one robot meets another. From this point the approaches to further mapping differs. While in some approaches the robots continue to create maps independently, in others all the robots contribute to one global map cooperatively.

A very simplified map merging approach with rendezvous is discussed in [12] by Roy and Dudek. Once the two robots meet, their produced local maps are merged manually. Of course, this is not a suitable solution if robots are to be completely autonomous.

A more sophisticated mapping approach is used by Roumeliotis and Bekey [10], who use a Kalman Filter for mapping. Their Kalman Filter approach differs from those mentioned earlier. While approaches described previously assume either that robots create the global map simultaneously or that the initial positions of the robots are known, this approach assumes neither. Each robot constructs its own map independently and these maps can be merged when two robots meet during the mapping process. Although the authors use Kalman Filter primarily for localization, they note that the algorithm can be easily adapted to map merging.

Ko et al. [7] use particle filters, an alternative to Kalman Filter, for the relative localization of robots. The initial starting positions of the robots are completely unknown and in order to verify that the two maps overlap an active location verification has to be performed. To verify the relative locations the robots agree on a rendezvous point. If they fail to meet, the hypothesis about relative locations is discarded and the map merging is not performed.

The particle filter concept for the multi-robot mapping is also utilized by Howard [23]. He assumes that the robots encounter each other at some time during the exploration and are able to correctly determine their relative positions. When the meeting occurs, the robots further contribute their observations to a common global map in one reference frame and the subsequent meetings of these two robots are ignored. The interesting part of the algorithm is that the already collected environment observations are added to the global map in a backwards manner. Thus, the map merging procedure is not really performed. Instead it appears that for a while two 'virtual' robots are contributing to the mapping process.

Bergasa et al. [24] use the particle filters together with the scan matching to achieve the generation of a highly accurate local maps of the individual robots. When two robots meet, the map merging process is performed; however, it is very simplified. The authors of this approach note that very accurate relative position detection is required for the maps from two robots to be merged correctly. Even a very small orientation error causes the construction of an inaccurate global map.

\section{Map Merging when the Relative Positions of the Robots Are Unknown}

All the multi-robot mapping approaches described above require that the relative positions of the robots are known at the start or the positions are acquired during the mapping. Without the positional information these approaches cannot merge the maps. The task of fusing maps without any positional information is a harder case of the map merging that requires different solutions. Most of the map merging methods of this type use the transformations' approach. They rotate and translate one of the maps against the other to find the best possible match.

The complexity of the map merging when the relative positions of the robots are unknown can differ greatly depending on the type of the maps. The maps that are most often used for mapping are metric maps and topological maps. The metric maps describe the geometric properties of the environment and are usually represented as occupancy grids, i.e., metric arrays where the value in each cell represents the probability of the responding location being free space or a part of the obstacle [16]. The alternative is topological maps that represent the environment as a graph where vertices 
represent the features (i.e. junctions) of the environment and edges represent paths between these features [13].

In practice, the merging of topological maps has proved to be easier than the merging of metric maps. Several researchers have addressed this problem and offered reasonable solutions [13], [25].

Dedeogle and Sukhatme [25] are one of the first researchers to address the problem of topological map merging. They developed the algorithm that matches the pairs of vertices to find the best possible transformation of the maps. The best transformation is one with the highest number of overlapping vertices. Only the vertices of similar type are compared, thus the transformation space is significantly reduced.

The topological map merging approach presented by Huang and Beevers [13] combines subgraph matching and image registration to find the potential transformations of the maps. There is one more notable difference from the approach described before, i.e., the transformations are computed by using clusters of multiple vertices. Thus, fewer transformations are verified and consequently the best transformation is acquired faster. This approach can be effectively used for rendezvous mapping, for the authors also provide a mechanism for the later verification of the map merging results [13].

It must be noted that both of the mentioned topological map merging methods use topological maps augmented with metric information. Without such information the topological map merging problem would become a mere search for identical subgraphs. The subgraphs can be found quite easily; however, the acquired result is much less reliable. Therefore, all considerable multi-robot topological mapping approaches use the metric information.

The metric map merging is a harder problem than the topological map merging as one has to rely on the metric information alone and no graph matching techniques can be used. To make the problem easier many researchers use metric maps that are augmented with some additional information.

One such example is Konolige et al. [8] who supplements an occupancy grid map with features to achieve a better map merging result. The use of features allows to significantly reduce the transformation space, thus the result is acquired faster. One serious problem of this map merging method, however, is the identification of the features in the occupancy grid map.

Adluru et al. [26] use similar feature maps for map merging. However, the map merging method itself is quite different. It addresses the problem as if the partial maps were sensor readings of a 'virtual robot'. The algorithm then uses a particle filter to merge all the maps into one global map. The features are used for the search of correspondences between local maps.

A different approach is offered by Amigoni and Gasparini [14]. They use a specific type of maps, i.e., segment maps acquired with 2D laser range sensors. The segment map consists of multiple segments and it is possible to calculate angles between consecutive segments. This property is then used as a heuristic for the search of the best transformation. It is presumed that the best transformation is the one with the largest sum of the common segment lengths.

Lakaemper et al. [27] concentrates on the problem of merging a different type of segment maps. In this case the maps are acquired by simplifying the raw sensor data into few polylines. The map merging algorithm then extracts parts of the map and searches corresponding polylines in the other map. When similar structures with significant shape information are found, the two maps are aligned. The hypothesis is then confirmed or rejected by checking the alignment of other polylines in the maps.

A map merging solution for a very specific type of the maps is presented by Williams et al. [28] The environment objects are represented as point features. The points are treated as graphs and the correspondence between the maps are found by searching the common subgraphs. Though in some ways similar, the point feature maps, however, are not topological maps as no navigational information is incorporated between the separate points. This kind of approach is quite original for metric maps; however, its areas of application are quite limited.

Another interesting approach is devised by Ho and Newman [15]. In addition to the geometric information the robots also collect information about the visual appearance of the environment. The images are collected and related to the according parts of the metric maps. When it is necessary to merge the local maps of two robots, the images are compared. To avoid false matches, the metric information is taken into account. However, it is not practical to use this map merging approach if the visual information of the environment is not distinctive.

All the map merging methods described above use some kind of structural or feature information to merge the maps if the relative positions of the robots are unknown. Not many researchers have addressed this problem when only geometric information is available. In fact, the only researchers to propose reasonable map merging solutions without simplifying or supplementing the occupancy grid maps are Carpin and Birk [16], [29].

Their map merging method presented in [29] rotates and translates the partial occupancy grid maps to find the best transformation. The best transformation is determined by using image similarity metric. To reduce the time required to merge the maps a stochastic random walk algorithm is used for the search of the transformation space. In [16] this map merging approach is complemented by the acceptance metric which determines the reliability of the map merging result. However, there is one serious drawback to this method as the used stochastic algorithm is guaranteed to find the optimal solution only if the number of iterations tend to infinite. Thus, it does not guarantee the best transformation when a limited number of iterations are executed.

Aware of this problem, Carpin [30] proposes another solution to the occupancy grid merging. The new approach uses Hough transform, a methodology used to detect geometric curves, to find the best transformations. This approach yields good results as it is fast, deterministic and 
capable of returning multiple hypothetic transformations. The main drawback of the algorithm is that it relies heavily on the existence of geometric curves in both maps. If such curves do not exist, it is problematic for the algorithm to rotate the maps correctly.

\section{The Characteristics OF the MaP Merging Methods}

By analyzing the existing map merging approaches and their applications, several characteristics, essential for the choice of one particular map merging approach, were identified:

- The reference frames;

- The type of the maps;

- The map merging decision;

- The structure of the environment;

- The enabler of the map merging;

- The duration of the map merging.

The relative positions of the robots and the type of the maps are popular characteristics used for the classification of the map merging methods while the rest are considered less often. It must be noted that there are other characteristics that could be regarded in the context of the map merging, i.e. different scale of the maps. However, these other characteristics are seldom taken into account as the map merging problem is hard enough as it is. Also different mapping techniques are not considered, for their influence mainly shows as restrictions for the characteristics listed above.

\section{A. The Reference Frames}

Essentially the map merging is the fusion of several local robot-made maps into one global map [7]. All the map merging methods can be classified in three separate groups depending on the moment when the relative reference frames of the local maps are acquired and the maps are merged:

- The relative starting positions of the robots are known and all the robots start the mapping in the common reference frame [2], [4], [5].

- The initial relative starting positions of the robots are unknown. However, it is assumed that robots meet some time during the exploration to acquire the relative positions and determine the relative reference frames of their local maps [7], [10], [12]. The strategy when robots need to meet to merge the local maps is called rendezvous.

- The initial relative reference frames of the local maps are unknown and the robots do not determine their relative positions during the exploration [8], [13], [14]. Consequently the relative reference frames cannot be determined by using relative positions of the robots and other approaches have to be used.

\section{B. The Type of the Maps}

It is evident in the map merging overview that the maps used for the mapping are very different. In the 1980s and early 1990s the dominant map types were metric and topological maps [1].
The metric maps describe the geometric properties of the environment and are usually represented as occupancy grids [16]. The topological maps represent the environment as a graph where vertices represent the features of the environment and edges represent paths between these features [13]. The line between the metric and topological maps, however, has become quite fuzzy as often topological maps are augmented with metric information or metric maps supplemented with features.

Nowadays, primarily three map types are used for the mapping and map merging:

- $\quad$ Metric maps [2], [4], [5];

- Metric maps with features [15], [28];

- Topological maps [13], [25].

This classification assumes that all the topological maps are augmented with some kind of metric information, for strictly topological maps aren't used anymore. Another assumption is that the features incorporated into metric maps can be different. For example, occupancy grid map supplemented with images is also considered to be a feature map.

It must be noted that some map merging approaches merge the maps without modifying them [16] while other approaches modify the maps and then merges the resulting maps [8]. This is often the case with the metric maps when features are extracted from the metric information. In the classification, however, only the unmodified maps should be considered as they are the original data source for the map merging method.

\section{The Map Merging Decision}

For the map merging result to be reliable, it must be certain that the maps have some common part [8]. The decision about the map merging is dependent of the knowledge about the relative reference frames of the maps:

- If the relative reference frames are known initially or acquired during rendezvous, the decision is easy to make, as it is possible to safely determine if the local maps have common parts or not.

- If the relative reference frames are never determined, it is impossible to make a reliable decision without external information about the existence of overlaps. In this case an unverified decision is made in order to merge the maps.

Sometimes the robots communicate during the mapping but are not able to determine their relative positions. In such case it is possible to find the best map merging hypothesis without any knowledge about the existence of the overlap and then verify the correctness of this hypothesis by further exploration. The original maps should be preserved in case the hypothesis is disproved.

It can be concluded that one of three types of map merging decisions can be made by map merging method:

- Verified decision - it is known for sure that the maps overlap;

- Unverified decision - it is not known if the maps overlap;

- Verifiable decision - it is not known if the maps overlap but it is possible to verify it later. 


\section{The Structure of the Environment}

The environment can be either structured or unstructured. The mapping of the unstructured environments is a problem that has received less attention than mapping of the structured environments [1]. Following this tendency, most of the map merging methods are intended for structured indoor environments and relatively few approaches are capable of dealing with unstructured environments.

The applicability of the map merging method for different environments is often related to the type of the maps. The topological maps are intended for the mapping of the structured environments. It is therefore not possible to use topological map merging methods when the environment is unstructured. If metric maps with features are used for the mapping, the situation is quite similar to the topological mapping as there are usually no distinctive features in the unstructured environments. When strictly metric maps are generated during the mapping, the applicability of the map merging methods for different structures of the environment can be divided into two groups:

- If the maps are not modified for the map merging purposes then it is possible to apply the map merging method for unstructured environments.

- If the maps are modified for the map merging purposes then it is usually not possible to apply the map merging method for unstructured environments.

\section{E. The Enabler of the Map Merging}

Besides the decision about the map merging initiation there is one more decision that has to be made during the map merging process. It is the decision about the way the maps will be mutually aligned. There are two main approaches that enable this kind of decision:

- The relative positions of the robots;

- Heuristics.

If the relative positions of the robots are known or determined during the mapping, it is possible to acquire the relative reference frames of the local maps [2], [4], [5]. Thus, the map merging is relatively easy. However, it is not always possible to determine the relative positions. In such case the relative reference frames of the local maps are acquired with the help of some heuristic [8], [13], [14]. Some rendezvous map merging approaches use both map merging enablers for a more accurate result [7].

\section{F. The Duration of the Map Merging}

A significant characteristic of the map merging methods is the time required for the map merging. It is, however, very hard to quantitatively compare the time necessary for different map merging methods. Many researchers have paid more attention to other characteristics of the map merging methods. Therefore quantitative evaluation of the map merging speed is often not available. Even if the quantitative data on the map merging speed is available, it is not a trivial matter to compare different map merging methods as different sizes and types of maps may be used. To compare the map merging time of different map merging methods a comprehensive research, where different methods were implemented and quantitatively tested, would be required.

An attractive alternative to the quantitative evaluation is a qualitative evaluation. The qualitative evaluation assesses the time required for the map merging qualitatively, i.e. it estimates the possibility of using the particular map merging method in real-time mapping. Of course, it is necessary to determine the threshold that cannot be exceeded if the map merging approach is to be considered an online approach. It might be, for example, one second.

By using qualitative evaluation it is sometimes possible to determine if the map merging method is applicable to realtime domains even if no quantitative evaluation is given. This might be the case if the method is implemented and tested with actual robot teams.

\section{V.THE RELATIONS OF THE MAP MERGING CHARACTERISTICS}

The identified characteristics of the map merging methods were analyzed and their possible values were determined (see Table 1). The acquisition of the possible values can be found in the Section IV.

When the characteristics and their possible values were identified, they were analysed in order to acquire interrelations. It turned out that the characteristic that affects other characteristics the most is the reference frame characteristic. Depending on the value of the reference frame characteristic, the values of other three characteristics - the map merging decision, the enabler of the map merging, and the duration of the map merging - are restricted (see Table 2). For example, if the relative reference frames of the local maps are known or acquired during the mapping then the map merging decision is always verified. On the other hand, if the relative reference frames of the local maps are not determined, then the map merging decision is never verified. Instead, it is either unverified or verifiable. This value depends on the particular map merging method.

It can be seen in Table 2 that the characteristics of the map type and the environment structure do not depend on the reference frame characteristic. Yet both these characteristics are interdependent. The possible values that the environment structure characteristic can assume are dependent of the map type characteristic value (see Table 3 ). The topological maps and feature maps can only be used for the mapping of the structured environments. On the other hand, metric maps can also be used for the mapping of the unstructured environments. However, some of the metric map merging approaches depend on the existence of the features in the environment and cannot be used if this condition isn't fulfilled.

By combining all the identified relations between the characteristics, the interrelations of all the characteristics were acquired (see Table 4). The relations of the topological maps and feature maps with the structure of environment are identical. Therefore, both these values of the map type characteristic are united in the global characteristic interrelation table. It must be noted that some relations, which depend on both the reference frames and the map type, are 
clarified in the global table. If the relative reference frames are unknown or are acquired during the rendezvous, and topological/feature maps are used then the duration of the map merging is online.

Besides the interrelations of the characteristics the Table 4 also shows the characteristics of the particular map merging approaches.

TABLE 1

The Possible VAlues of THE MaP Merging Characteristics

\begin{tabular}{|l|l|}
\hline The characteristic & $\begin{array}{l}\text { Possible values of the } \\
\text { characteristic }\end{array}$ \\
\hline The reference frames & Known; Rendezvous; Unknown \\
\hline The type of the maps & Metric; Topological; Feature \\
\hline The map merging decision & Verified; Unverified; Verifiable \\
\hline The structure of the environment & $\begin{array}{l}\text { Structured; Structured and } \\
\text { Unstructured }\end{array}$ \\
\hline The enabler of the map merging & Relative positions; Heuristics \\
\hline The duration of the map merging & Online; Offline \\
\hline
\end{tabular}

TABLE 2

THE RELATIONS OF THE REFERENCE FRAME CHARACTERISTIC WITH OTHER CHARACTERISTICS

\begin{tabular}{|l|l|l|l|}
\hline $\begin{array}{l}\text { The reference } \\
\text { frames }\end{array}$ & $\begin{array}{l}\text { The map } \\
\text { merging } \\
\text { decision }\end{array}$ & $\begin{array}{l}\text { The enabler of } \\
\text { the map } \\
\text { merging }\end{array}$ & $\begin{array}{l}\text { The } \\
\text { duration }\end{array}$ \\
\hline Known & Verified & Positions & Online \\
\hline Rendezvous & Verified & $\begin{array}{l}\text { Positions and/or } \\
\text { Heuristics }\end{array}$ & $\begin{array}{l}\text { Online or } \\
\text { Offline }\end{array}$ \\
\hline Unknown & $\begin{array}{l}\text { Unverified or } \\
\text { Verifiable }\end{array}$ & Heuristics & $\begin{array}{l}\text { Online or } \\
\text { Offline }\end{array}$ \\
\hline
\end{tabular}

TABLE 3

THE RELATION OF THE MAP TYPE CHARACTERISTIC WITH THE ENVIRONMENT STRUCTURE CHARACTERISTIC

\begin{tabular}{|l|l|}
\hline The type of the maps & The structure of the environment \\
\hline Metric & Structured and Unstructured \\
\hline Topological & Structured \\
\hline Feature & Structured \\
\hline
\end{tabular}

THE RELATIONS OF THE MAP MERging Characteristics

\begin{tabular}{|l|l|l|l|l|l|l|}
\hline $\begin{array}{l}\text { The relative } \\
\text { positions of the } \\
\text { robots }\end{array}$ & $\begin{array}{l}\text { The type of the } \\
\text { maps }\end{array}$ & $\begin{array}{l}\text { The map } \\
\text { merging decision }\end{array}$ & $\begin{array}{l}\text { The enabler of the } \\
\text { map merging }\end{array}$ & $\begin{array}{l}\text { Time required for } \\
\text { the map merging }\end{array}$ & $\begin{array}{l}\text { The structure of } \\
\text { the environment }\end{array}$ & $\begin{array}{l}\text { The map } \\
\text { merging } \\
\text { approaches }\end{array}$ \\
\hline \multirow{3}{*}{ Known } & Metric & Verified & Relative positions & Online & $\begin{array}{l}\text { Structured and } \\
\text { Unstructured }\end{array}$ & $\begin{array}{l}{[2],[4],[5],[9],} \\
{[17],[19]}\end{array}$ \\
\cline { 2 - 7 } & $\begin{array}{l}\text { Topological or } \\
\text { Feature }\end{array}$ & Verified & Relative positions & Online & Structured & {$[11],[20]-[22]$} \\
\hline \multirow{3}{*}{ Rendezvous } & Metric & Verified & $\begin{array}{l}\text { Relative positions } \\
\text { and/or Heuristics }\end{array}$ & Online or Offline & $\begin{array}{l}\text { Structured and } \\
\text { Unstructured }\end{array}$ & $\begin{array}{l}{[7],[10],[12],} \\
{[23],[24]}\end{array}$ \\
\cline { 2 - 7 } & $\begin{array}{l}\text { Topological or } \\
\text { Unknown }\end{array}$ & Veature & $\begin{array}{l}\text { Relative positions } \\
\text { and/or Heuristics }\end{array}$ & Online & Structured & {$[13]$} \\
\cline { 2 - 7 } & Metric & $\begin{array}{l}\text { Unverified or } \\
\text { Verifiable }\end{array}$ & Heuristics & Online or Offline & $\begin{array}{l}\text { Structured and } \\
\text { Unstructured }\end{array}$ & $\begin{array}{l}{[8],[16],[26],} \\
{[29],[30]}\end{array}$ \\
\cline { 2 - 7 } & Feature & $\begin{array}{l}\text { Unverified or } \\
\text { Verifiable }\end{array}$ & Heuristics & Online & Structured & $\begin{array}{l}{[13]-[15],[25],} \\
{[27],[28]}\end{array}$ \\
\hline
\end{tabular}




\section{ACKNOWLEDGEMENT}

This work has been supported by the European Social Fund within the project "Support for the implementation of doctoral studies at Riga Technical University".

\section{REFERENCES}

[1] S. Thrun, "Robotic mapping: a survey," in Exploring Artificial Intelligence in the New Millennium. Morgan Kaufmann, 2002, pp. 1-35.

[2] W. Burgard, M. Moors, and F. Schneider, "Collaborative exploration of unknown environments with teams of mobile robots," in Advances in Plan-Based Control of Robotic Agents, Lecture Notes in Computer Science, Vol. 2466. Berlin/Heidelberg: Springer, 2002, pp. 187-215.

[3] I. Andersone, "Space exploration with multiple agents," Master thesis, Riga Technical University, Riga, 2009.

4] R. Simmons, et al., "Coordination for multi-robot exploration and mapping," in AAAI National Conference on Artificial Intelligence, August 2000. Austin: AAAI, 2000.

[5] K. Ishioka, K. Hiraki, and Y. Anzai, "Cooperative map generation by heterogeneous autonomous mobile robots," in IJCAI'93 Workshop on Dynamically Interacting Robots, August 1993. Chambery, 1993, pp. $57-$ 67.

[6] L. E. Parker, "Current state of the art in distributed autonomous mobile robotics," in 5th International Symposium on Distributed Autonomous Robotic Systems, October 2000. Knoxville: Springer, 2000, pp. 3-12.

7] J. Ko, et al., "A practical decision-theoretic approach to multi-robot mapping and exploration," in IEEE/RSJ International Conference on Intelligent Robots and Systems, October 2003. Nevada, 2003, pp. 3232 3238

[8] K. Konolige, et al., "Map merging for distributed robot navigation," in IEEE/RSJ International Conference on Intelligent Robots and Systems, October 2003. Nevada, 2003, pp. 212-217.

[9] R. Madhavan, K. Fregene, and L. E. Parker, "Distributed heterogeneous outdoor multi-robot localization," in IEEE International Conference on Robotics and Automation, May 2002. Washington, 2002, pp. 374-381.

[10] S. I. Roumeliotis and G. A. Bekey, "Distributed multirobot localization," IEEE Transactions on Robotics and Automation, vol. 18, no. 5, 2002, pp. 781-795.

[11] N. S. V. Rao, "Terrain model acquisition by mobile robot teams and nconnectivity," in 5th International Symposium on Distributed Autonomous Robotic Systems, October 2000. Knoxville: Springer, 2000, pp. 231-240.

[12] N. Roy and G. Dudek, "Collaborative robot exploration and rendezvous: algorithms, performance bounds and observations," Autonomous Robots, vol. 11. US: Springer, 2000, pp. 117-136.

[13] W. Huang and K. Beevers, "Topological map merging," The International Journal on Robotics Research, vol. 24, no. 8. Sage Science Press, 2005, pp. 601-613.

[14] F. Amigoni, S. Gasparini, and M. Gini, "Merging partial maps without using odometry," in Multi-Robot Systems. From Swarms to Intelligent Automata, vol. III. Netherlands: Springer, 2005, pp. 133-144.

[15] K. Ho and P. Newman, "Multiple map intersection detection using visual appearance," in 3rd International Conference on Computational Intelligence, December 2005. Singapore, 2005.

[16] A. Birk and S. Carpin, "Merging occupancy grid maps from multiple robots," in Proceedings of the IEEE, vol. 94. IEEE, 2006, pp. 1384 1397.
[17] S. Thrun, W. Burgard, and D. Fox, "A real-time algorithm for mobile robot mapping with applications to multi-robot and 3D mapping," in IEEE International Conference on Robotics and Automation, April 2000. San Francisco: IEEE, 2000, pp. 321-328.

[18] S. Thrun, "A probabilistic online mapping algorithm for teams of mobile robots," International Journal of Robotics Research, vol. 20. Sage Science Press, 2001, pp. 335-363.

[19] A. Howard, G. S. Sukhatme, and M. J.Matarie, "Multi-robot mapping using manifold representations," in IEEE International Conference on Robotics and Automation, April 2004, Vol. 4. New Orleans: IEEE, 2004, pp. 4198-4203.

[20] J. W. Fenwick, P. M. Newman, and J. J. Leonard, "Cooperative concurrent mapping and localization," in IEEE International Conference on Robotics and Automation, May 2002. Washington: IEEE, 2002, pp. 1810-1817.

[21] D. Rodriguez-Losada, F. Matia, and A. Jimenez, "Local maps fusion for real time multirobot indoor simultaneous localization and mapping," in IEEE International Conference on Robotics and Automation, April 2004, Vol. 2. New Orleans: IEEE, 2004, pp. 1308-1313.

[22] N. Ceccarelli, et al., "Set membership localization and map building for mobile robots," in Systems \& Control: Foundations \& Applications, Part III. Boston: Birkhauser, 2006, pp. 289-308.

[23] A. Howard, "Multi-robot simultaneous localization and mapping using particle filters," The International Journal on Robotics Research, vol. 25, no. 12. Sage Science Press, 2006, pp. 1243-1256.

[24] P. Bergasa, et al., "SLAM and map merging," Journal of Physical Agents, vol. 3, no. 1, 2009.

[25] G. Dedeoglu and G. Sukhatme, "Landmark-based matching algorithm for cooperative mapping by autonomous robots," in Distributed Autonomous Robotics Systems, October 2000. USA: Springer, 2000, pp. 251-260.

[26] N. Adluru, et al., "Merging maps of multiple robots," in 19th International Conference on Pattern Recognition, December 2008. Tampa: IEEE, 2008, pp. 1-4.

[27] R. Lakaemper, L. J. Latecki, and D. Wolter, "Incremental multi-robot mapping," in IEEE/RSJ International Conference on Intelligent Robots and Systems, August 2005. Edmonton, 2005, pp. 3846-3851.

[28] S. B. Williams, G. Dissanayake, and H. Durrant-Whyte, "Towards multi-vehicle simultaneous localisation and mapping," in IEEE International Conference on Robotics and Automation, May 2002. Washington: IEEE, 2002, pp. 27-43.

[29] S. Carpin and A. Birk, "Stochastic map merging in rescue environments," in RoboCup 2004: Robot Soccer World Cup VIII, Lecture Notes in Computer Science, Vol. 3276. Berlin/Heidelberg: Springer, 2005, pp. 483-490.

[30] S. Carpin, "Fast and accurate map merging for multi-robot systems," Autonomous Robots, vol. 25. USA: Kluwer Academic Publishers, 2008, pp. 305-316.

Ilze Andersone was born in Riga, Latvia. She received a B.Sc. degree in computer control and computer science in 2007. In 2009 she received a M.Sc. degree in computer systems. Both degrees were acquired at Riga Technical University, Riga, Latvia.

She has been working at Department of Systems Theory and Design, Riga Technical University, since 2007. Her research interests include robotic mapping, robot teams, and image registration.

Ilze Andersone. Karšu apvienošanas metožu raksturiezīmju apskats

Autonomu mobilo robotu izstrāde ir populārs pētījumu lauks mākslīgajā intelektā jau vairāk nekā divdesmit gadus. Būtisks priekšnosacījums autonomu robotu izstrādē ir spēja sastādīt apkārtējās vides karti. Tomēr robotu karšu sastādīšanā rodas vairākas problēmas, kuras vēl arvien nav līdz galam atrisinātas. Robotu komandu pielietošana karšu sastādīšanā atrisina dažas no šīm problēmām, bet šajā gadījumā rodas arī vairākas jaunas problēmas, kas ir specifiskas tieši vairāku robotu karšu sastādīšanai. Viena no problēmām robotu komandu karšu sastādīšanā ir robotu sastādīto lokālo karšu apvienošana vienā kopīgā globālā kartē. Robotu komandu pielietošana telpas izpētē un karšu sastādīšanā ir samērā jauna pētījumu joma un sākotnēji vairāku robotu karšu sastādīšanas metodes bija viena robota karšu sastādīšanas metožu paplašinājums. L̄idz ar to arī karšu apvienošanas problēma tika vienkāršota. Karšu apvienošanas pētījumi ir attīstījušies samērā nesen, tāpēc esošās publikācijas par karšu apvienošanu apraksta tikai specifiskas karšu apvienošanas metodes, un neeksistē vispusīgi apskati par vispārējo stāvokli karšu apvienošanas jomā. Tāpēc šĩ raksta mērkis ir aprakstīt esošo situāciju karšu apvienošanas jomā un identificēt galvenās karšu apvienošanas metožu raksturiezīmes. Kad ir identificētas raksturiezīmes, ir iespējams noteikt to savstarpējās sakarības un noteikt katrai raksturiezīmju grupai atbilstošās karšu apvienošanas metodes.

Илзе Андерсоне. Характерные особенности методов объединения карт: обзор

Разработка автономных мобильных роботов - это популярная область исследования в искусственном интеллекте уже более двадцати лет. Важной предпосылкой для создания автономного робота является способность создания карты окружающей среды. Однако, в области составления карт 
роботами до сих пор имеются некоторые неокончательно решённые проблемы. Использование группы роботов для составления карт решает некоторые из этих проблем, но в этом случае возникают новые проблемы, специфичные для составления карт несколькими роботами. Одна из таких проблем - это объединение всех локальных карт, созданных группой роботов, в одну глобальную карту. Применение групп роботов в исследовании пространства и составлении карт является относительно новой отраслью исследований; вначале методы составления карт многими роботами просто были расширением методов составления карт одним роботом. В связи с этим проблема объединения карт была упрощена. Исследования в области объединения карт начали развиваться относительно недавно, и поэтому имеющиеся публикации об объединении карт описывают только специфичные методы объединения карт, и не существует разносторонних обзоров об общем состоянии в отрасли объединения карт. Поэтому целью данной статьи является описать существующую ситуацию в области объединения карт и выделить главные характерные особенности методов объединения карт. После определения характерных особенностей становится возможным определить их взаимосвязи, а также для каждой группы таких взаимосвязей определить соответствующие методы объединения карт. 